\title{
Electrochemical removal of Bisphenol A from landfill leachate under Nordic climate conditions
}

\author{
Noëmi Ambauen ${ }^{1}\left[\right.$ Clara Weber $^{1} \cdot$ Jens Muff $^{2} \cdot$ Cynthia Hallé$^{1} \cdot$ Thomas Meyn $^{1}$
}

Received: 2 May 2020 / Accepted: 1 September 2020 / Published online: 12 September 2020

(c) The Author(s) 2020

\begin{abstract}
This study investigated the applicability of electrochemical oxidation for landfill leachate treatment in climate areas, where cold temperatures prevail (like Northern Norway). Experiments were completed with pre-treated (coagulation/flocculation and separation) landfill leachate at 6 and $20^{\circ} \mathrm{C}$ in order to assess the temperature influence on the degradation of the organic pollutant Bisphenol A and the fate of the ordinary wastewater parameters COD and nitrate. Furthermore, two different anode materials (Ti/Pt and Nb/BDD) and three different current densities (10, 43 and $86 \mathrm{~mA} \mathrm{~cm}^{-2}$ ) were compared. Additionally, the formation of the two groups of disinfection by-products, trihalomethanes and perchlorate, was monitored. A $99 \%$ removal of Bisphenol A was confirmed at $6{ }^{\circ} \mathrm{C}$ on both tested anode materials, but a current density of at least $43 \mathrm{~mA} \mathrm{~cm}{ }^{-2}$ must be applied. Removal rates were on average $38 \%$ slower at $6{ }^{\circ} \mathrm{C}$ than at $20^{\circ} \mathrm{C}$. For comparison, Bisphenol A removal in clean electrolyte disclosed faster degradation rates (between 50 and 68\%) due to absent landfill leachate matrix effects. The energy consumption for $99 \%$ Bisphenol A removal was 0.28 to $1.30 \mathrm{kWh} \mathrm{m}^{-3}$, and was on average $14 \%$ higher at $6{ }^{\circ} \mathrm{C}$ compared to $20^{\circ} \mathrm{C}$. Trihalomethanes were mainly formed on Pt anodes in the ppb range, while perchlorate was primarily formed at BDD anodes in the ppm range. Formation of disinfection by-products increased with increased applied current and temperature. Electrochemical oxidation was found to be a suitable treatment process for landfill leachate in cold climate areas by successfully meeting treatment goals.
\end{abstract}

Noëmi Ambauen

noemi.ambauen@ntnu.no

Clara Weber

claratw@ntnu.no

Jens Muff

jm@bio.aau.dk

Cynthia Hallé

cynthia.halle@ntnu.no

Thomas Meyn

thomas.meyn@ntnu.no

1 Department of Civil- and Environmental Engineering,

Norwegian University of Science and Technology, S.P.

Andersens Veg 5, Trondheim, Norway

2 Department of Chemistry and Bioscience, Aalborg

University, Niels Bohrs Vej 8, Esbjerg, Denmark 


\section{Graphic abstract}
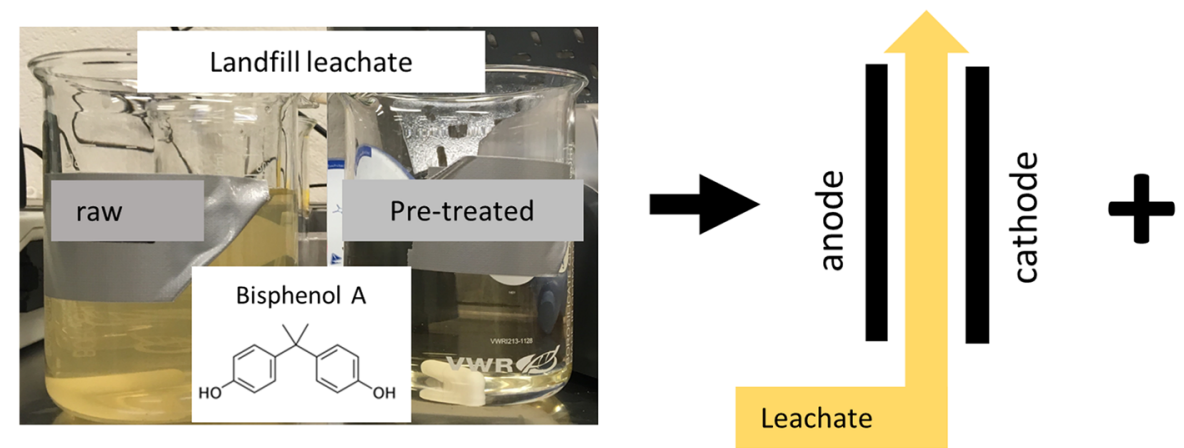

Nordic climate
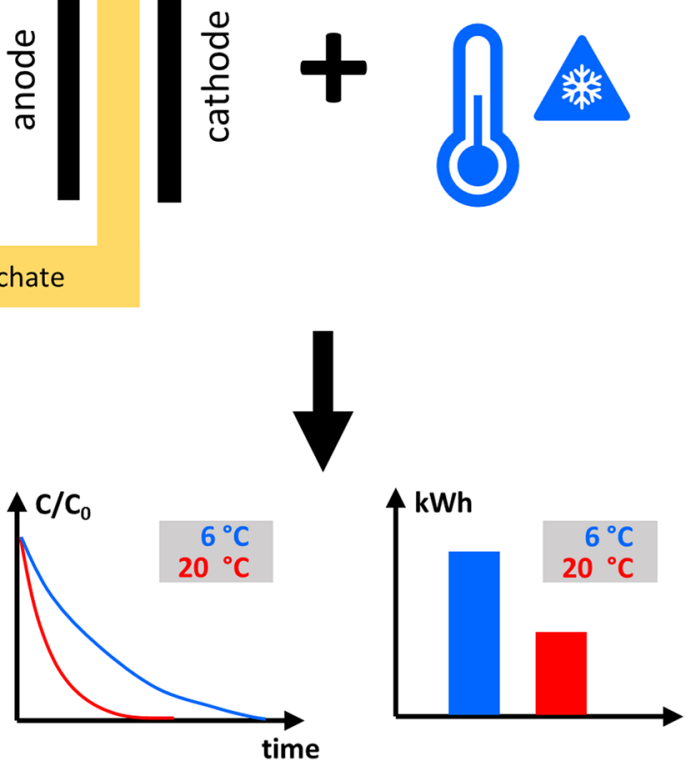

Keywords Bisphenol A · Applied current · Temperature $\cdot$ Energy consumption · Disinfection by-products $\cdot$ Organic pollutants

\section{Introduction}

Several advanced oxidation processes (AOPs) have been assessed for their suitability to treat different kind of wastewaters. Among AOPs, electrochemical oxidation (EO) has gained great attention because large amounts of water can be treated, no residual waste is produced, and no addition of chemicals is needed [1]. Several studies investigated the performance of EO to remove common wastewater parameters form landfill leachate (LL). For instance, Panizza et al. [2] successfully removed chemical oxygen demand (COD) from LL to below the disposal limit $\left(160 \mathrm{mg} \mathrm{L}^{-1}\right)$ and de Oliveira et al. [3] reported a COD removal of $90 \%$ or higher. Satisfactory removal of ammonium nitrogen $\left(\mathrm{NH}_{3}-\mathrm{N}\right)$ from LL of up to $100 \%$ by EO has been reported by Li et al. [4]. A substantial advantage of using EO to treat LL and other wastewaters is that also refractory organic compounds can be removed due to the production of the highly reactive hydroxyl radicals [5]. Hereby, it has to be distinguished between active and non-active anode material, which either form chemisorbed or physisorbed hydroxyl radicals [6, 7]. Oxidation of refractory organic compounds can also take place via indirect oxidation [8]. The most prominent indirect oxidation pathway is via the oxidation of $\mathrm{Cl}^{-}$ions to active chlorine ( $\mathrm{HOCl}$ and $\mathrm{OCl}^{-}$, depending on $\left.\mathrm{pH}\right)$, which further react with organic pollutants leading to their partial oxidation [9]. Oxidation via hydroxyl radicals or mediating oxidizing species, allows for the removal of e.g. pharmaceuticals and personal care products (PPCPs) [10] or fulvic- and humic like substances [11]. Other recalcitrant compounds being leached from everyday items such as Bisphenol A (BPA) [12] can also be removed successfully by EO [13]. Oturan et al. [14] specifically studied the degradation of polycyclic aromatic hydrocarbons (PAHs), volatile organic carbons (VOCs) and polychlorinated biphenyls (PCBs) contained in LL and observed an electrochemical removal of those compounds between 80 and $100 \%$.

The above-mentioned studies were all completed either at room temperature or in climate areas, where fairly warm temperatures dominate. In general, wastewater treatment systems typically work more efficiently in moderate to warm temperatures because growth rates are higher, chemical reactions are faster, treatment times are shorter and consequently energy costs are lower [15]. A few studies can be found on psychrophilic biological wastewater treatment. Smith et al. [16] reported a stable COD removal during psychrophilic anaerobic wastewater treatment, indicating a promising potential for its application in cold climate regions. 
Kettunen et al. [17] compared anaerobic and sequential anaerobic treatment of LL at 11 and $24{ }^{\circ} \mathrm{C}$. They reported that at $11^{\circ} \mathrm{C}$ and a hydraulic retention time (HRT) of 1.5 to 2 days, a COD removal of $65 \%$ was achieved while at $24{ }^{\circ} \mathrm{C}$ and an HRT of $10 \mathrm{~h} \mathrm{75 \%}$ of the COD was removed. These findings suggest a clear adverse impact of cold temperatures on the wastewater treatment efficiency. However, no studies exist up to date that assess the performance of chemical wastewater treatment like EO in cold climate regions, a knowledge gap addressed in this article. This is also very relevant with regard to an increased focus on the technology in arctic regions. The LL for this study is collected on a site close to the city of Mosjøen, Norway, which lays in the subarctic climate zone with an average yearly air temperature of $3.6{ }^{\circ} \mathrm{C}$. The yearly average $\mathrm{LL}$ temperature is $6{ }^{\circ} \mathrm{C}$, which is higher than the average air temperature due to the isolating properties of the soil. A preliminary study [18] showed that BPA can be successfully removed from a model electrolyte solution at $6{ }^{\circ} \mathrm{C}$ by $\mathrm{EO}$ experiments.

The aim of this study was to assess the impact of the Nordic climate on the performance of EO treatment for LL and evaluate its feasibility for application at low temperatures. Due to LL treatment regulations, an important focus was the removal of specific organic pollutants such as BPA. BPA is abundantly present in the collected leachate from the landfill in Mosjøen and is listed on the Norwegian list of priority substance and must be removed below detection limit $\left(0.11 \mu \mathrm{g} \mathrm{L}^{-1}\right.$ or $\left.5 \mathrm{nM}\right)$ after treatment. EO performance at the yearly average temperature of the LL $\left(6{ }^{\circ} \mathrm{C}\right)$ was compared to room temperature $\left(20^{\circ} \mathrm{C}\right)$ and two different anode materials (active: Ti/Pt and non-active: $\mathrm{Nb} /$ BDD) as well as three different applied currents (10, 43 and $86 \mathrm{~mA} \mathrm{~cm}^{-2}$ ) were evaluated. Additionally, the formation of trihalomethanes (THMs) and perchlorate were studied as known disinfection by-products (DBPs) during EO of chloride containing waters and are of major concern $[19,20]$. A full factorial design approach with replicates was chosen to conduct the study.

\section{Methods}

\subsection{Landfill leachate characteristics}

LL for this study was pretreated on-site with coagulation/ flocculation using $\mathrm{FeCl}_{3}$ as a coagulant, followed by a lamella clarifier. The $\mathrm{pH}$ was adjusted with $\mathrm{NaOH}$ to about $\mathrm{pH} 10$ in order to have optimum conditions for particle and heavy metal removal during coagulation/flocculation. The supernatant of the lamella clarifier was used to perform the experiments carried out in this study. The LL was spiked with additional BPA before experiments to obtain an initial concentration of $5.0 \mu \mathrm{M}$. 100-fold higher concentration for the experiments was chosen for a better monitoring of the degradation over time due to the detection limit of the analytical method. Furthermore, due to batch variations, the original BPA concentration varied a lot, spiking of BPA allowed to obtain equal initial concentrations. No household waste is disposed in the SHMIL landfill. Solely special industrial waste like gypsum and asbestos waste, sand from sand traps, slag, sludge from oil separators and hazardous waste such as caustic, toxic and highly flammable waste are disposed on site. Consequently, the leachate composition is based on the disposed waste. Its characteristics are summarized in Table 1.

\subsection{Experimental set-up}

The experimental set-up (Fig. 1) consisted of an electrochemical flow cell (ElectroCell Europe AS, Denmark), a $5 \mathrm{~L}$ solution tank, a chiller (FP50-ME, Julabo GmbH, Germany) and a peristaltic pump (Masterflex Cole-Parmer Instrument Co., USA). Anode material was either $\mathrm{Nb} / \mathrm{BDD}$ or $\mathrm{Ti} / \mathrm{Pt}$ and cathode was stainless steel. The square shaped active electrode area is $10 \mathrm{~cm}^{2}$ with an interelectrode gap of $4 \mathrm{~mm}$ (Fig. 1). A turbulence enhancing mesh was installed between anode and cathode. Both electrodes were cooled with tab water from their rear side. The LL was pumped via Teflon tubing from the tank through the electrochemical flow cell and back. LL in the tank was continuously stirred by means of a magnetic stirrer and its temperature was kept stable with the connected chiller. The experiments were carried out under galvanostatic conditions, i.e. with a constant applied current, a duration of $240 \mathrm{~min}$ and volume of $2.5 \mathrm{~L}$.

\subsection{Experimental design}

The experiments were carried out following a full factorial design. An overview of the factors and factors level is given in Table 2.

A total of 24 experiments have been conducted, including replicates. Several response factors $\left(\mathrm{Y}_{\mathrm{i}}\right)$ have been chosen and are described by their corresponding linear regression

Table 1 Overview of landfill leachate characteristics

\begin{tabular}{lll}
\hline Parameter & Unit & LL (pre-treated) \\
\hline $\mathrm{pH}$ & - & 9.9 \\
$\mathrm{COD}$ & $\mathrm{mgO}_{2} \mathrm{~L}^{-1}$ & 99.5 \\
$\mathrm{BOD}_{5}$ & $\mathrm{mgO}_{2} \mathrm{~L}^{-1}$ & $<10$ \\
TOC & $\mathrm{mg} \mathrm{L}^{-1}$ & 39.5 \\
sum PAH & $\mu \mathrm{g} \mathrm{L}^{-1}$ & 0.32 \\
BTEX & $\mu \mathrm{g} \mathrm{L}^{-1}$ & 2.99 \\
Bisphenol A & $\mu \mathrm{g} \mathrm{L}^{-1}$ & 11 \\
Ammonium $\left(\mathrm{NH}_{4}^{+}\right)$ & $\mathrm{mg} \mathrm{L}^{-1}$ & 72.8 \\
\hline
\end{tabular}




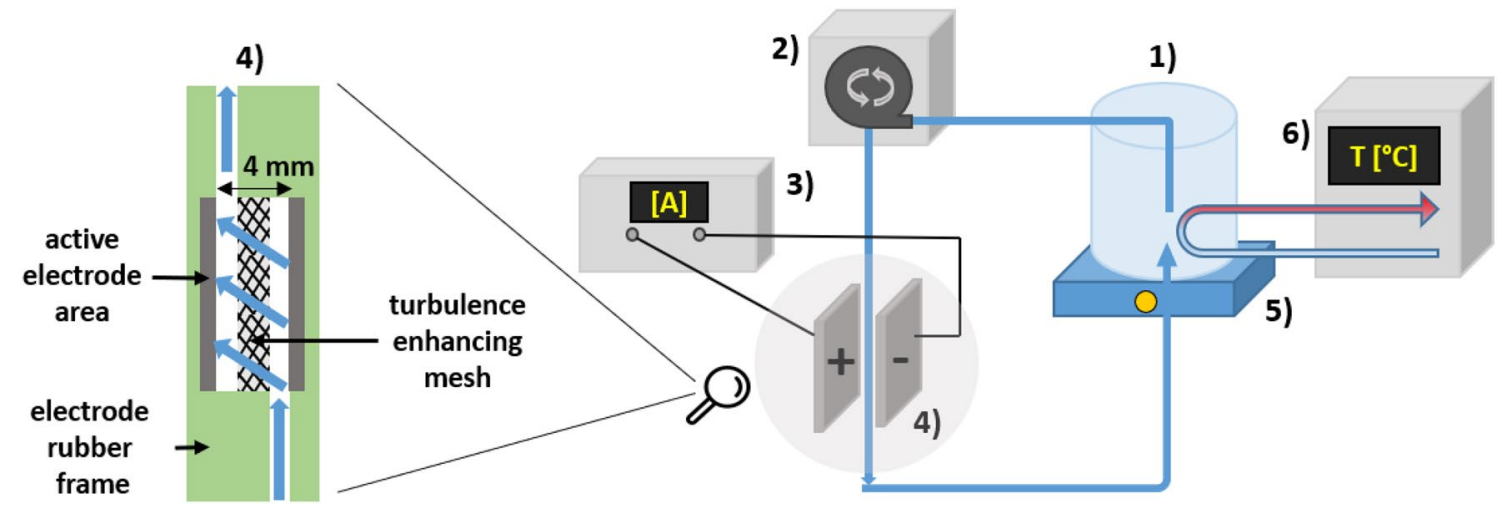

Fig. 1 Experimental set-up; 1: solution tank, 2: peristaltic pump, 3: potentiostat, 4: electrochemical flow cell, 5: magnetic stirrer, 6: chiller with cooling coil

Table 2 Overview of factors and factor levels implemented in the full factorial design

\begin{tabular}{llll}
\hline Factor & Level of factor & & \\
\hline Temperature $\left({ }^{\circ} \mathrm{C}\right)$ & 6 & 20 & \\
Anode material & $\mathrm{Pt}$ & BDD & \\
Applied current $\left(\mathrm{mA} \mathrm{cm}^{-2}\right)$ & 10 & 43 & 86 \\
\hline
\end{tabular}

model (Eq. 1). The statistical software Minitab (Minitab Inc., USA) was used for statistical analysis and estimation of the model parameters $\left(b_{0}-b_{7}\right)$. Experiments also followed a random order generated by Minitab.

$Y=b_{0}+b_{1} A+b_{2} B+b_{3} C+b_{4} A B+b_{5} A C+b_{6} B C+b_{7} A B C$

Y: response variable; b0: constant (intercept); b1-b7: coefficients; A-ABC: main- and interaction effects.

The null hypothesis $\left(\mathrm{H}_{0}\right)$ assumed that no factor is significantly affecting the response variable $\left(\right.$ Effect $\left._{j}=0\right)$, while the alternative hypothesis $\left(\mathrm{H}_{1}\right)$ assumed that least one factor significantly affected the response $\left(\right.$ Effect $\left._{j} \neq 0\right)$. A significance level of $5 \%(\alpha=0.05)$ was chosen.

\subsection{Chemicals}

Bisphenol A was used to spike the LL was purchased from Sigma-Aldrich (Merck, USA) and had a purity grade of $99 \%$. BPA stock solution was prepared in $100 \%$ acetonitrile (VWR, Avantor, USA). Deuterated (d16) Bisphenol A (analytical grade) was used as internal standard for BPA and purchased from Sigma-Aldrich. THMs standard mix (analytical grade) and the corresponding internal standard dichloromethane (analytical grade) were purchased form Sigma-Aldrich. Orthophosphoric acid (85\%), used to preserve TOC samples was purchased from VWR. Sodium thiosulfate was used to quench the samples and was purchased from Sigma-Aldrich. Solvents used for liquid chromatography, methanol, acetonitrile, as well as ammonium acetate were purchased from VWR (HPLC purity grade). Chemicals and solvents used for ion chromatography, sodium bicarbonate, sodium carbonate, acetone, oxalic acid and sulfuric acid were purchased from Sigma-Aldrich (analytical grade). Deionized water was provided in the local laboratory by an Elga PURELAB $®$ Ultra, Type I + device.

\subsection{Analytical methods}

Cuvette tests from Hach (Hach Co., USA) were used to measure ammonium $\mathrm{NH}_{4}{ }^{+}$(LCK 303, $2-47 \mathrm{mgNH}_{4}-\mathrm{N}$ $\left.\mathrm{L}^{-1}\right)$, nitrate $\mathrm{NO}_{3}{ }^{-}\left(\mathrm{LCK} 339,0.23-13.5 \mathrm{mgNO}_{3}-\mathrm{N} \mathrm{L}^{-1}\right)$ and chemical oxygen demand COD (LCK 314, 15-150 $\mathrm{mgO}_{2}$ $\mathrm{L}^{-1}$ ). The cuvette tests were analyzed with a Hach DR3900 laboratory spectrophotometer for water analysis. Free chlorine $\left(\mathrm{HClO} / \mathrm{ClO}^{-}\right)$was measured with a Hach Pocket Colorimeter $^{\mathrm{TM}} \mathrm{II}$, using the N,N-diethyl-p-phenylenediamine (DPD) method with a LOQ of $0.1 \mathrm{mgCl}_{2} \mathrm{~L}^{-1}$.

Total organic carbon (TOC) was measured with the TOC analyzer Apollo 9000 (Tekmar, Teledyne Technologies, USA). Prior to measurement, samples were diluted 10 times and preserved by adding an adequate amount of concentrated phosphoric acid to obtain a final sample $\mathrm{pH}$ between 2-3. Measurement procedure followed the Norwegian standard NS EN 1484 [21] and has an LOQ of $0.5 \mathrm{mgC} \mathrm{L}^{-1}$.

Perchlorate measurements were conducted with an ion chromatography 940 Professional IC Vario (Metrohm, Switzerland) along with a 858 Professional Sample Processor (Metrohm). A high-performance Metrosep A Supp5 (Metrohm) separation column was used with dimensions $250 \times 4.0 \mathrm{~mm}$ and a $5 \mu \mathrm{m}$ particle size. A flow rate of $0.7 \mathrm{~mL} \mathrm{m^{-1 }}$ was applied and a LOQ of $0.32 \mathrm{mg} \mathrm{L}^{-1}$ was determined. The software MagIC Net 3.2 (Metrohm) was used to measure the samples and results were analyzed using Excel (Microsoft, USA). 
Quantification of Bisphenol A (BPA) was done by a UPC $^{2}$ (Waters, USA) with XEVO TQ-S triple quadrupole mass spectrometer (Waters) with an Aquity $\mathrm{UPC}^{2} \mathrm{BEH}$ $1.7 \mu \mathrm{m}$ column (Waters). Compressed $\mathrm{CO}_{2}$ (solvent $\mathrm{A}$ ) and methanol with $10 \mathrm{mM}$ ammonium acetate (solvent B) were used as liquid phases and $100 \%$ methanol for the make-up flow. The respective flow rate and make-up flow rate were set to $2.5 \mathrm{~mL} \mathrm{~min}^{-1}$ and $0.8 \mathrm{~mL} \mathrm{~min}^{-1}$ and an automated backpressure of 1500 psi was applied. The LOQ was determined to $5.0 \mathrm{nM}$ BPA. Masslynx (Waters) and Targetlynx (Waters) were the softwares used for measurement and data analysis respectively. Samples were dried using a SpeedVac vacuum concentrator SPD300DDA (Thermo Fischer Scientific, USA) and reconstituted in analytical grade 2-isopropanol (VWR) prior to measurement.

THMs were quantified with a headspace injector (Tekmar HT3, Teledyne Technologies, USA) coupled to a GC-MS (GC/MS Triple quad 7000, Agilent, USA). Quenched samples $(10 \mathrm{~mL})$ were placed in $20 \mathrm{~mL}$ crimp cap sealed head space vials. Headspace analysis was done using a trap column (Purge/Trap K Vocarb® 3000, Supelco, USA) and a DB-624 UI GC column (Agilent) with a length of $30 \mathrm{~m}, 0.25 \mathrm{~mm}$ diameter and $1.40 \mu \mathrm{m}$ film thickness. The LOQ for trichloromethane $\left(\mathrm{CHCl}_{3}\right)$, bromodichloromethane $\left(\mathrm{CHCl}_{2} \mathrm{Br}\right)$, chlorodibromomethane $\left(\mathrm{CHClBr}_{2}\right)$ and tribromomethane $\left(\mathrm{CHBr}_{3}\right)$ are $3 \mathrm{ppb}$, $6 \mathrm{ppb}, 6 \mathrm{ppb}$ and $6 \mathrm{ppb}$ respectively. Samples were measured using Masshunter software (Agilent) and Masshunter Quant software (Agilent) was used for sample analysis and quantification.

\section{Results and discussion}

\subsection{Experimental reproducibility}

The experimental design was carried out with replicates. Table 3 summarizes the averaged response parameters (SI:1) together with their coefficient of variation $(\mathrm{CV})$, which is the ratio of the standard deviation and the mean of the two replicate experiments. The $\mathrm{CV}$ is unitless and allows therefore to compare the dispersion of the two replicated values also in between two different factors. A high CV value indicates higher dispersion. As can be seen in Table 3, the CVs vary greatly between the different factors for the same experimental conditions. This observation may be explained by the different measurement methods for the corresponding response factor (BPA, $\mathrm{COD}, \mathrm{NO}_{3}{ }^{-}$and THMs), which are afflicted with different measurement uncertainties. In addition, the different measurement methods were carried out by different personnel, another source contributing to the observed inter-factor $\mathrm{CV}$ variation. $\mathrm{CV}$ also shows variability for the same response factor but different experimental conditions.

\subsection{Removal of Bisphenol A}

The degradation of BPA over time at different applied currents and temperatures is shown in Fig. 2. No complete removal could be achieved at $10 \mathrm{~mA} \mathrm{~cm}^{-2}$, but higher removal of BPA was reached at BDD anodes (Fig. 2b, d) than at Pt anodes (Fig. 2a, c), while the applied temperature only played a secondary role. At higher applied currents, 43 and $86 \mathrm{~mA} \mathrm{~cm}^{-2}$ (Fig. 2), complete BPA removal was achieved for all experimental conditions. At

Table 3 Average response factor of each replicated experiment, grouped after experimental factorial combination

\begin{tabular}{|c|c|c|c|c|c|c|c|c|c|c|}
\hline Temp $\left({ }^{\circ} \mathrm{C}\right)$ & $\mathrm{j}_{\text {app }}\left(\mathrm{mA} \mathrm{cm}^{-2}\right)$ & Anode (-) & $\mathrm{BPA}\left(\mathrm{min}^{-1}\right)$ & $\mathrm{CV}_{\mathrm{BPA}}(\%)$ & $\operatorname{COD}(\%)$ & $\mathrm{CV}_{\mathrm{COD}}(\%)$ & $\mathrm{NO}_{3}^{-}(\%)$ & $\mathrm{CV}_{\mathrm{NO} 3}(\%)$ & $\Sigma \mathrm{THM}(\mathrm{ppb})$ & $\mathrm{CV}_{\mathrm{THM}}(\%)$ \\
\hline 6 & 10 & $\mathrm{Pt}$ & 0.002 & 85.8 & 0.3 & 0.6 & 15.9 & 15.5 & 6.8 & 64.0 \\
\hline 6 & 10 & $\mathrm{BDD}$ & 0.007 & 10.4 & 10.4 & 24.6 & 72.7 & 5.9 & 10.0 & 1.6 \\
\hline 6 & 43 & $\mathrm{Pt}$ & 0.023 & 10.1 & 10.1 & 55.4 & 41.1 & 35.0 & 72.8 & 33.0 \\
\hline 6 & 43 & BDD & 0.044 & 3.9 & 8.9 & 34.4 & 40.3 & 8.9 & 27.6 & 1.7 \\
\hline 6 & 86 & $\mathrm{Pt}$ & 0.118 & 9.9 & 16.2 & 0.4 & 85.0 & 4.0 & 200.8 & 6.9 \\
\hline 6 & 86 & BDD & 0.070 & 7.5 & 9.9 & 3.8 & 34.3 & 10.4 & 27.0 & 2.1 \\
\hline 20 & 10 & $\mathrm{Pt}$ & 0.003 & 18.2 & 1.6 & 74.7 & 14.4 & 13.6 & 8.1 & 25.6 \\
\hline 20 & 10 & BDD & 0.006 & 6.6 & 12.5 & 3.0 & 82.0 & 7.8 & 5.1 & 9.9 \\
\hline 20 & 43 & $\mathrm{Pt}$ & 0.036 & 7.9 & 15.7 & 14.9 & 68.4 & 17.4 & 88.0 & 10.5 \\
\hline 20 & 43 & BDD & 0.093 & 0.4 & 13.7 & 9.3 & 69.8 & 3.5 & 23.9 & 4.2 \\
\hline 20 & 86 & $\mathrm{Pt}$ & 0.164 & 1.7 & 23.5 & 8.0 & 99.6 & 10.5 & 143.3 & 21.0 \\
\hline 20 & 86 & BDD & 0.220 & 21.6 & 16.9 & 3.6 & 55.2 & 5.3 & 30.1 & 21.1 \\
\hline
\end{tabular}

Corresponding coefficient of variation is given to the right 

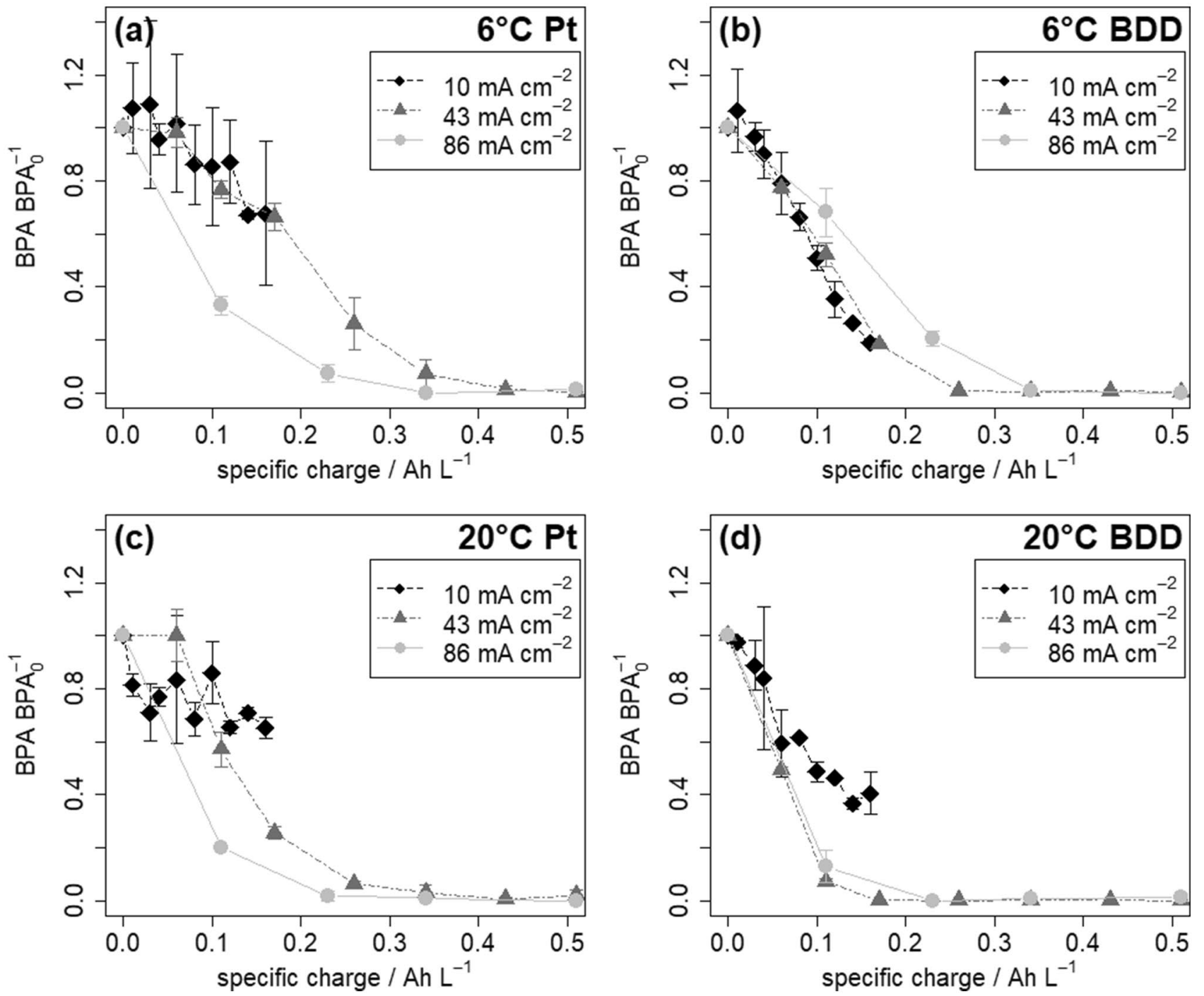

Fig. 2 Degradation of BPA in LL vs specific charge (Ah $\left.\mathrm{L}^{-1}\right)$ until complete removal or maximal experimental time was reached: $\mathbf{a}$ Pt and $6{ }^{\circ} \mathrm{C}$, b BDD and $6{ }^{\circ} \mathrm{C}, \mathbf{c ~ P t}$ and $20^{\circ} \mathrm{C}, \mathbf{d ~ B D D}$ and $20^{\circ} \mathrm{C}$; Error bars indicate the standard deviation of the two replicate experiments

Pt anode (Fig. 2a, c), complete BPA removal was reached at $86 \mathrm{~mA} \mathrm{~cm}^{-1}$ after less specific charged passed than at an applied current of $43 \mathrm{~mA} \mathrm{~cm}{ }^{-1}$. A higher applied temperature did not change the specific charged passed at $86 \mathrm{~mA} \mathrm{~cm}^{-1}$ for complete BPA removal but lead to a lower specific charge passed at $43 \mathrm{~mA} \mathrm{~cm}^{-1}$ to completely remove BPA. On BDD anode (Fig. $2 \mathrm{~b}$, d) at $6{ }^{\circ} \mathrm{C}$ a higher specific charged passed at $86 \mathrm{~mA} \mathrm{~cm}^{-1}$ than at $43 \mathrm{~mA} \mathrm{~cm}^{-1}$ until complete removal of BPA. This behaviour was also observed at BDD anode and $20^{\circ} \mathrm{C}$ but the difference in the specific charge passed between 43 and $86 \mathrm{~mA} \mathrm{~cm}^{-1}$ for complete BPA removal is marginal compared to $6{ }^{\circ} \mathrm{C}$. This may be attributed to the higher applied current that not only favours BPA degradation, but also unwanted side reactions, which are more expressed for
BDD and can be confirmed by a lower charge efficiency constant (Fig. 3b), as discussed below.

These above made observations are supported by the statistical analysis of variance. Current density, temperature and the interaction between those two and the interaction between temperature and anode material were identified as significant effects (SI:2). The corresponding regression equation is given in SI:4 with an adjusted coefficient of determination $\left(\mathrm{R}_{\text {adj }}^{2}\right)$ corresponding to $88.9 \%$. These observations are confirmed when looking at the reaction rate constants $\left(k_{B P A}\right)$, graphically summarized (Fig. 3a, c) and their exact numbers can be found in Table 3 . The reaction rates were calculated using a first order kinetic model fitted to the experimental data over time. The difference for $k_{B P A}$ for the two different anode materials at $10 \mathrm{~mA} \mathrm{~cm}^{-2}$ corresponds to 

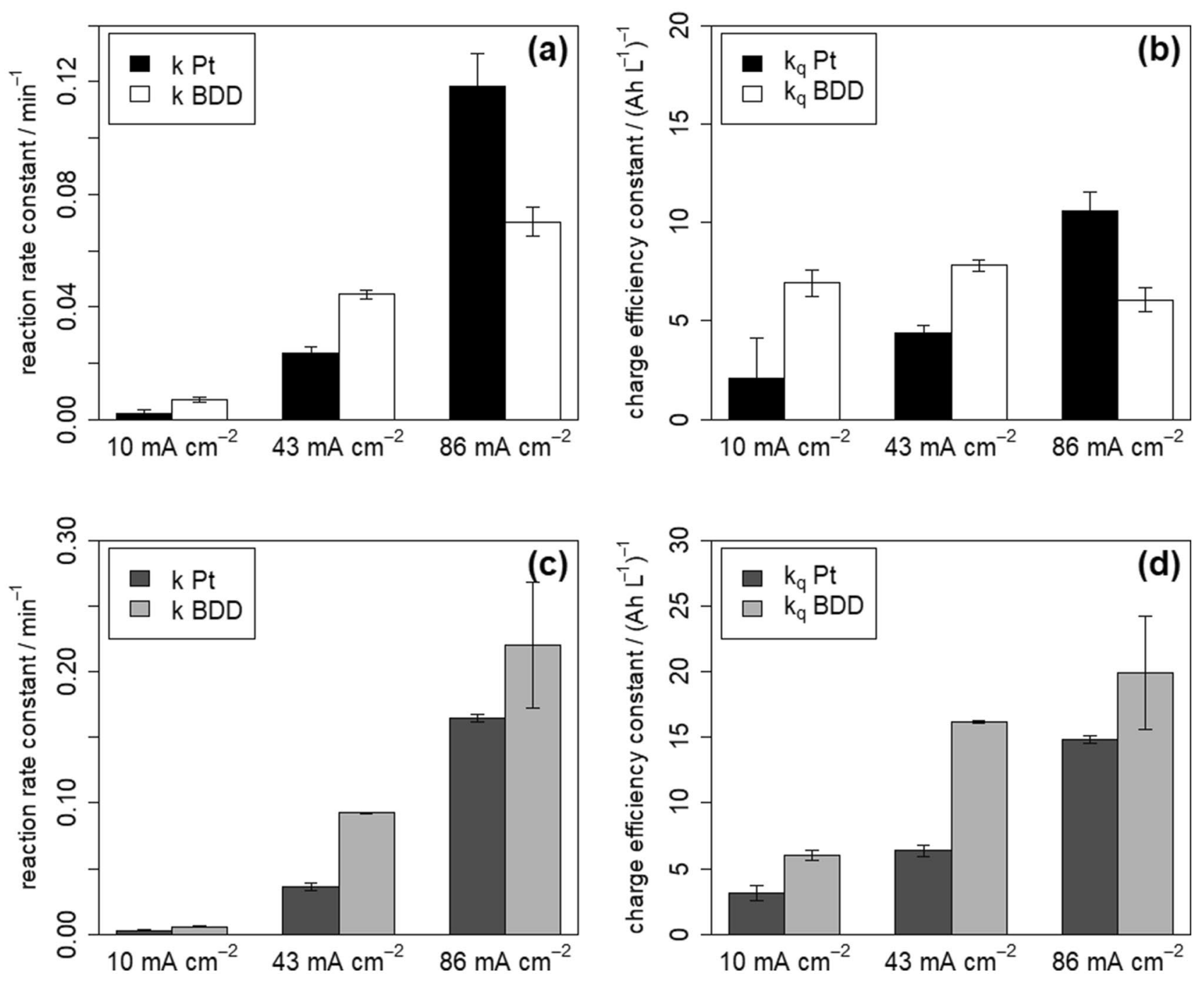

Fig. 3 Comparison of reaction rates and current efficiencies for BPA: a reaction rate constants $(\mathrm{k})$ at $6{ }^{\circ} \mathrm{C}$, b charge efficiency constant $\left(\mathrm{k}_{\mathrm{q}}\right)$ at $6{ }^{\circ} \mathrm{C}$, c reaction rate constants at $20^{\circ} \mathrm{C}, \mathbf{d}$ charge efficiency constant at $20^{\circ} \mathrm{C}$

$72 \%$ and $55 \%$ at 6 and $20{ }^{\circ} \mathrm{C}$ respectively. At the same current, the temperature difference only altered $k_{B P A}$ by $25 \%$ and $20 \%$ for Pt and BDD anode respectively. This clearly shows that the temperature influence was considerably smaller than the influence of anode material, when the lowest current was applied $\left(10 \mathrm{~mA} \mathrm{~cm}^{-2}\right)$. The influence of the different applied temperatures was bigger at $43 \mathrm{~mA} \mathrm{~cm}^{-2}$ where $k_{B P A}$ differed by $35 \%$ and $52 \%$ on Pt and BDD anode respectively. The effect of the anode material was in the same range for 10 and $43 \mathrm{~mA} \mathrm{~cm}^{-2}$ and caused a difference of $k_{B P A}$ of $47 \%$ and $61 \%$ at 6 and $20{ }^{\circ} \mathrm{C}$ respectively. It is visible that the cold temperature plays a more important role by causing a larger difference in $k_{B P A}$ at a higher applied current $\left(43 \mathrm{~mA} \mathrm{~cm}^{-2}\right)$ than at $10 \mathrm{~mA} \mathrm{~cm}^{-2}$, where the anode material had a higher impact. Still, the anode material causes a larger difference of $k_{B P A}$ than the temperature, also at $43 \mathrm{~mA} \mathrm{~cm}^{-2}$. At the highest applied current $\left(86 \mathrm{~mA} \mathrm{~cm}^{-2}\right)$, the influence of temperature on $k_{B P A}$ was lower on Pt anode than on BDD anodes and caused differences of $k_{B P A}$ of $28 \%$ and $68 \%$ respectively. The anode material caused a variation of $k_{B P A}$ at $86 \mathrm{~mA} \mathrm{~cm}-2$ of $68 \%$ and $25 \%$ for 6 and $20{ }^{\circ} \mathrm{C}$ respectively.

From the results above it can be concluded that $6{ }^{\circ} \mathrm{C}$ lead in general to a slower $k_{B P A}$ than $20^{\circ} \mathrm{C}$. An exception to this statement is the parameter combination BDD and $10 \mathrm{~mA} \mathrm{~cm}{ }^{-2}$, where $6{ }^{\circ} \mathrm{C}$ resulted in a factor $1.3(20 \%)$ faster $k_{B P A}$ than $20^{\circ} \mathrm{C}$. According to literature [22, 23] and the Arrhenius's law that predicts slower kinetics at lower temperatures, it was expected a priori that the parameter combination $6{ }^{\circ} \mathrm{C}$, Pt anode and $10 \mathrm{~mA} \mathrm{~cm}^{-2}$ would lead to the slowest BPA degradation. On the other side, the fastest BPA degradation was expected at $20{ }^{\circ} \mathrm{C}$, BDD anode and $86 \mathrm{~mA} \mathrm{~cm}^{-2}$. Both presumptions were confirmed with 
respective reaction rate constants, which differ by $99 \%$. It can further be concluded that BDD anode resulted generally in faster $k_{B P A}$ than Pt anodes. Again, there is one exception to this statement where the opposite was observed. At $6{ }^{\circ} \mathrm{C}$ and $86 \mathrm{~mA} \mathrm{~cm}^{-2}$, a factor 1.7 (68\%) faster $k_{B P A}$ was observed at Pt than on BDD anode (Fig. 3a) \%. Lastly, when comparing the different $k_{B P A}$ among the different current densities (Fig. 3a, c) it is evident that an increasing applied current results in increasing $k_{B P A}$, which applies for both anode materials and both temperatures, with no exception. A linear correlation between an increasing $k_{B P A}$ and the increasing applied current density could be found for BDD but not for Pt anode (SI: 8).

The reaction rate constants $\left(k_{B P A}\right)$ give valuable insights into the rate of degradation, but they do not account for the current efficiency during EO of BPA. In order to consider the relative current efficiency, the charge efficiency constant $\left(k_{q}\right)$ for BPA was calculated, adapted from Muff et al. [24] (Eq. 2):

$$
\frac{d[B P A]}{d Q}=-k_{q} *[B P A]
$$

Q: specific charge $\left(A h L^{-1}\right), k_{\mathrm{q}}$ : charge efficiency constant [(Ah L $\left.)^{-1}\right)^{-1}$ ], [BPA]: BPA concentration, normalized.

Figure 3 depicts the calculated $k_{B P A}$ and $k_{q}$ for BPA. At $6{ }^{\circ} \mathrm{C}$. An increase of $k_{B P A}$ is observed with increasing applied current, valid for both, Pt and BDD anode (Fig. 3a). On Pt anodes $6{ }^{\circ} \mathrm{C}, k_{q}$ increases with an increasing applied current similarly to $k_{B P A}$ (Fig. $3 \mathrm{~b}$ ). However, the relative difference between the different applied currents is smaller for the charge efficiency constant than for the reaction rate constants. The ratio of the charge efficiency constant is 2.1:2.4 and 11.9:5.1 for the reaction rate constant for the three different applied currents and increasing order. On the other hand, no increase of $k_{q}$ for BDD anode at $6{ }^{\circ} \mathrm{C}$ is observed. In fact, $k_{q}$ remains in the same range for all three different applied current and is slightly smaller at $86 \mathrm{~mA} \mathrm{~cm}^{-2}$ than at $10 \mathrm{~mA} \mathrm{~cm}^{-2}$ (Fig. 3b). This shows that the current efficiency is not lost at higher applied current, which is important in order maintain a fast and efficient process. The same pattern can be observed for the reaction rate constant at $20^{\circ} \mathrm{C}$ (Fig. 3c). An increase of $k_{q}$ on Pt anode with increasing applied current is observed, with a ratio (2.0: 2.3) similar to the one at $6{ }^{\circ} \mathrm{C}$ (Fig. 3d). Contrary to the observation at $6{ }^{\circ} \mathrm{C}$, an increase of $k_{q}$ can be observed on BDD anode at $20{ }^{\circ} \mathrm{C}$ (Fig. 3d). Muff et al. [24] observed that $k_{q}$ increased when the oxidation rate $(k)$ of their model organic compound (naphthalene) decreased. They attributed this behaviour to the suppression of the water oxidation side reaction, which is known to be more expressed at higher applied currents. This trend can be seen in the present study only for BDD anodes at $6{ }^{\circ} \mathrm{C}$. The best current efficiency at $6{ }^{\circ} \mathrm{C}$ was obtained at $43 \mathrm{~mA} \mathrm{~cm}^{-2}$ for BDD anode and at $86 \mathrm{~mA} \mathrm{~cm}^{-2}$ for Pt anode. At $20{ }^{\circ} \mathrm{C}$, the best current efficiency was at $86 \mathrm{~mA} \mathrm{~cm}^{-2}$ for both, Pt and BDD anode.

A preliminary study by Ambauen et al. [18] explored the degradation of $5.0 \mu \mathrm{M}$ BPA at $43 \mathrm{~mA} \mathrm{~cm}^{-2}$ and $\mathrm{pH} 10$ in clean electrolyte solution, containing $\mathrm{NaCl}$ and $\mathrm{Na}_{2} \mathrm{SO}_{4}$. Concentrations of $\mathrm{NaCl}$ and $\mathrm{Na}_{2} \mathrm{SO}_{4}$ were the same as found on average in the LL, 0.0033 and $0.0003 \mathrm{M}$ respectively. All the other experimental settings, pumping rate, experimental time and solution $\mathrm{pH}$ were the same as in the present study. Figure $2 b$ depicts the degradation in the LL matrix for the same experimental conditions as in the preliminary study. Table 4 summarizes the corresponding first order BPA reaction rate constants and their differences between the distinct solutions. Reaction rates for BPA in clear electrolyte solution (Table 4) were adapted from Ambauen et al. [18]. It is evident that BPA degradation followed the same pattern in both solutions. However, the matrix effect causes a reduction of BPA degradation rates of at least $50 \%$. Although the differences reductions are in the same range of magnitude, an increase is observed with decreasing temperature and when switching from BDD to $\mathrm{Pt}$ anode. An initial delay is observed on Pt anode (Fig. 2b) in the LL, whereas in the clean electrolyte BPA degradation started immediately. In clean electrolyte, active chlorine is formed at slower rates on Pt anodes than on BDD anodes [25]. The LL contains inorganic anions like $\mathrm{Cl}^{-}$and bicarbonate, which can act as hydroxyl radical scavengers. In turn, those scavenging reactions decelerate the $\mathrm{EO}$ of organic pollutants such as BPA. $\mathrm{Cl}^{-}$and the hypochlorite ion $\left(\mathrm{OCl}^{-}\right)$, the form of active chlorine present at $\mathrm{pH} 10$, react with hydroxyl radicals and thus act as scavengers (Eq. 4a, 4b) [26]:

$\mathrm{Cl}^{-}+\mathrm{HO}^{\bullet} \rightarrow \mathrm{ClOH}^{-}$

$\mathrm{OCl}^{-}+\mathrm{HO}^{\bullet} \rightarrow \mathrm{ClO}^{\bullet}+\mathrm{H}_{2} \mathrm{O}$

Bicarbonate $\left(\mathrm{HOC}_{3}^{-}\right)$and carbonate $\left(\mathrm{CO}_{3}{ }^{2-}\right)$ ions are contained in most aqueous solutions [27]. At $\mathrm{pH} 10$, these anions are present to $30 \%$ as $\mathrm{CO}_{3}{ }^{2-}$ and to $70 \%$ as $\mathrm{HCO}_{3}{ }^{-}$. Equation (5a) and (5b) depict the reactions for bicarbonate and carbonate ions with hydroxyl radicals [28].

Table 4 comparison first order BPA degradation rates $\left(\mathrm{min}^{-1}\right)$ in different solutions for $43 \mathrm{~mA} \mathrm{~cm}^{-2}$, pH 10 and 240 min treatment time

\begin{tabular}{llll}
\hline & $\begin{array}{l}\text { Clean electrolyte } \\
\mathrm{k}\left(\mathrm{min}^{-1}\right)\end{array}$ & $\begin{array}{l}\text { Landfill leachate } \mathrm{k} \\
\left(\mathrm{min}^{-1}\right)\end{array}$ & $\begin{array}{l}\text { Reduction } \\
\Delta \mathrm{k}(\%)\end{array}$ \\
\hline $6{ }^{\circ} \mathrm{C} / \mathrm{Pt}$ & 0.072 & 0.023 & 68 \\
$6^{\circ} \mathrm{C} / \mathrm{BDD}$ & 0.097 & 0.044 & 55 \\
$20^{\circ} \mathrm{C} / \mathrm{Pt}$ & 0.087 & 0.036 & 59 \\
$20^{\circ} \mathrm{C} / \mathrm{BDD}$ & 0.187 & 0.093 & 50 \\
\hline
\end{tabular}


$\mathrm{HCO}_{3}^{-}+\mathrm{HO}^{\bullet} \rightarrow \mathrm{HCO}_{3}^{-}+\mathrm{OH}^{-}$

$\mathrm{CO}_{3}^{2-}+\mathrm{HO}^{\bullet} \rightarrow \mathrm{CO}_{3}^{\cdot-}+\mathrm{OH}^{-}$

This circumstance combined with other occurring competing reactions caused by the LL matrix content constituents can explain the initial observed delay of BPA degradation on Pt anodes. The complex LL matrix slows down the degradation of BPA and consequently longer treatment times are required and are accompanied by higher costs.

In conclusion, these results show that it is possible to efficiently degrade the organic pollutant BPA to below detection limit under cold operating temperatures that are dominating in subarctic climate regions. The removal of the initial BPA concentration of $11 \mu \mathrm{g} \mathrm{L}^{-1}$ to below detection limit furthermore upgrades the effluent from class 3 (no chronical long term toxic effects) to class 2 (no toxic effects) according to the Norwegian guidelines for water classification [29]. However, the applied current densities must be reasonably high, i.e. at least $43 \mathrm{~mA} \mathrm{~cm}^{-2}$, in this study, in order to achieve complete BPA degradation within $4 \mathrm{~h}$ treatment time. Additionally, when choosing BDD over Pt as anode material, BPA degradation is in general promoted faster.

\subsection{Removal of COD}

While the TOC content remained relatively stable, a decrease of COD could be observed, indicating that most of the organic content of the LL was oxidized, but not mineralized (SI: 6). The applied current was the most significant factor influencing the COD degradation (Fig. 4). By increasing the current density from 10 to $86 \mathrm{~mA} \mathrm{~cm}^{-2}$, COD removal at $20^{\circ} \mathrm{C}$ increased from 2 to $23 \%$ and 13 to $17 \%$ for $\mathrm{Pt}$ and BDD anode respectively. At $6{ }^{\circ} \mathrm{C}, \mathrm{COD}$ removal was around $10 \%$ for BDD for all applied current densities. After

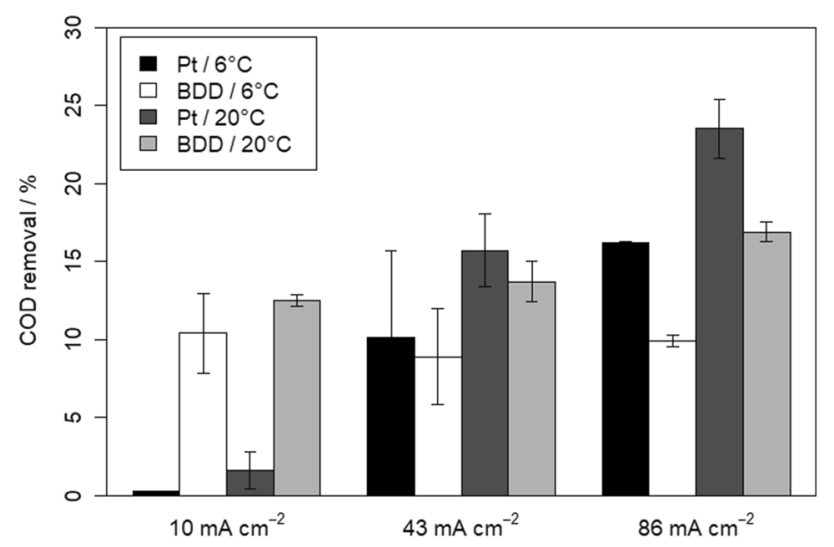

Fig. 4 COD degradation at different applied currents a slight increase of COD at the start, the COD was reduced by $16 \%$ at $6{ }^{\circ} \mathrm{C}$ on $\mathrm{Pt}$ anode.

Under similar conditions, the COD removal was in general higher on Pt anodes compared to BDD, except for $10 \mathrm{~mA} \mathrm{~cm}{ }^{-2}$. This is supported by the statistical analysis, that finds a significant interaction effect between the anode material and the applied current (SI: 2).

Zhou et al. [30] observed an increase in COD removal from reverse osmosis concentrate with increasing applied current, but stated that COD removal was always highest at non-active BDD compared to the active $\mathrm{Ti} / \mathrm{IrO}_{2}-\mathrm{RuO}_{2}$ anode, no matter the applied current. Contrary to this, de Moura et al. [30] found a higher COD removal percentage at Ti/Pt than at BDD anode for real waste water samples with an initial concentrations of $341 \mathrm{mg} \mathrm{L}^{-1} \mathrm{COD}$ and $208 \mathrm{mg} \mathrm{L}^{-1} \mathrm{Cl}^{-}(0.0036 \mathrm{M})$. After $2 \mathrm{~h}$ of treatment at $25^{\circ} \mathrm{C}$, they observed a COD removal of 25.2 and $1.0 \%$ for $\mathrm{Pt}$ and BDD anode respectively. They further observed an increase in COD removal by doubling the applied current from $25.2 \%$ to $30.5 \%$ at $\mathrm{Pt}$ anode and from $1.0 \%$ to $4.5 \%$ on BDD anode. This study observed the same as Zhou et al. [30] for $10 \mathrm{~mA} \mathrm{~cm}^{-2}$ but this behavior changes for 43 and $86 \mathrm{~mA} \mathrm{~cm}^{-2}$ where the observations are similar to the ones from de Moura et al. [31]. A possible explanation for this change in behavior might be the increasing current efficiency (CE) with decreasing applied current on BDD (Fig. 5). CE was calculated according to Eq. 6 [7]:

$C E_{C O D}=F V \frac{\left(C O D_{t}-C O D_{t+\Delta t}\right)}{8 I \Delta t}$

F: Faraday constant $\left(\mathrm{As} \mathrm{mol}^{-1}\right)$; V: volume (L); COD $\left(\mathrm{molO}_{2} \mathrm{~L}^{-1}\right)$ : I: current (A); $\mathrm{t}, \mathrm{t}+\Delta \mathrm{t}$ : time (s).

This leads to a reduced side reactions such as oxygen evolution [7] and thus COD is removed more efficiently at lower currents. The current efficiencies at $\mathrm{Pt}$ anodes are

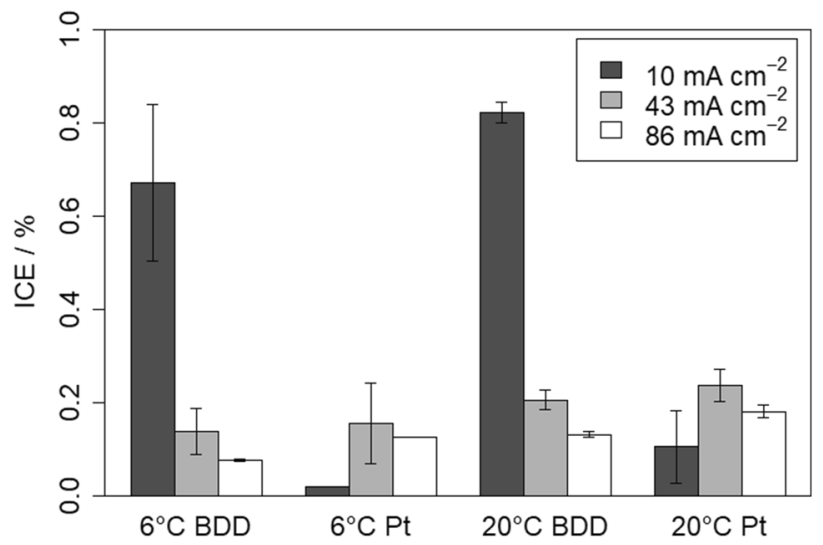

Fig. 5 ICE [\%] for COD removal at different temperatures and anode materials 
lowest at $10 \mathrm{~mA} \mathrm{~cm}^{-2}$ and highest at $43 \mathrm{~mA} \mathrm{~cm}^{-2}$. Furthermore, current efficiencies at 43 and $8610 \mathrm{~mA} \mathrm{~cm}^{-2}$ are always better at $\mathrm{Pt}$ than BDD anodes which is reflected in higher COD removal (Fig. 4) for those higher applied currents.

\subsection{Ammonium removal and nitrate formation}

The $\mathrm{pH}$ of the LL after pre-treatment was 9.9, which means that active chlorine species are present to $99.54 \%$ as $\mathrm{OCl}^{-}$and to $0.46 \%$ as $\mathrm{HOCl}$. At $\mathrm{pH} 9.9,30.1 \%$ of the ammonium is present as $\mathrm{NH}_{4}{ }^{+}$and the remaining $69.9 \%$ are present in form of $\mathrm{NH}_{3}$ (aq). A blank test with no applied current (data not shown) revealed that no $\mathrm{NH}_{3}$ is lost into the gas phase during the experimental time of $4 \mathrm{~h}$. During the $\mathrm{EO}$ of $\mathrm{NH}_{3}$ via indirect oxidation by $\mathrm{HOCl}$ [32] (Eq. 7) or $\mathrm{OCl}^{-}$[33] (Eq. 8) monochloramines $\left(\mathrm{NH}_{2} \mathrm{Cl}\right)$ can be formed. Their formation is assumed to have caused a large variance during $\mathrm{NH}_{4}{ }^{+}$measurements [34], which lead to discarding the measurements. Apart from chloramines, $\mathrm{NH}_{3}$ and $\mathrm{NH}_{4}{ }^{+}$can also be oxidized to elementary $\mathrm{N}_{2}$ or to $\mathrm{NO}_{3}{ }^{-}$respectively via indirect oxidation by $\mathrm{HOCl}($ Eqs. 9, 10) [35]. As most of the ammonium is present as $\mathrm{NH}_{3}$ and most of active chlorine as $\mathrm{OCl}^{-}$due to the high $\mathrm{LL} \mathrm{pH}$, the indirect oxidation to $\mathrm{N}_{2}$ or $\mathrm{NO}_{3}{ }^{-}$are assumed to take place but they only account for a marginal part. In addition, direct electron transfer at the BDD anode surface can lead to the oxidation of $\mathrm{NH}_{3}$ to $\mathrm{N}_{2}$ at high $\mathrm{pH}$ (Eq. 11) and $1.6 \mathrm{~V}$ vs. MSE (2.2 V vs. SHE) [32]. On Pt anode, direct oxidation of $\mathrm{NH}_{3}$ to $\mathrm{N}_{2}$ cannot take place due to the low oxygen evolution overpotential that starts at $1.9 \mathrm{~V}$ compared to BDD anode where oxygen evolution first starts at $2.6 \mathrm{~V}$ vs. SHE [7]. This suggest that the pathway proposed in Eq. 11 most likely took place on BDD anode. However, only the formation of $\mathrm{NO}_{3}{ }^{-}$could be measured in this study (Fig. 6) confirming only the pathway suggested in Eq. (10).

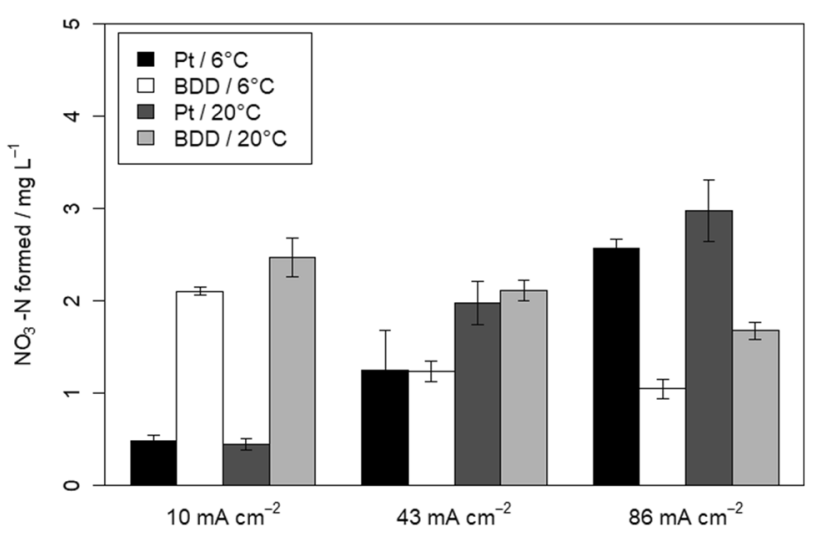

Fig. 6 Formation of nitrate $\left(\mathrm{NO}_{3}^{-}\right)$at different applied currents
$\mathrm{HOCl}+\mathrm{NH}_{3} \rightarrow \mathrm{NH}_{2} \mathrm{Cl}+\mathrm{H}_{2} \mathrm{O}$

$\mathrm{OCl}^{-}+\mathrm{NH}_{3} \rightarrow \mathrm{NH}_{2} \mathrm{Cl}+\mathrm{OH}^{-}$

$2 \mathrm{NH}_{3}+3 \mathrm{HOCl} \rightarrow \mathrm{N}_{2}+3 \mathrm{H}_{2} \mathrm{O}+3 \mathrm{H}^{+}+3 \mathrm{Cl}^{-}$

$\mathrm{NH}_{4}^{+}+4 \mathrm{HOCl} \rightarrow \mathrm{NO}_{3}^{-}+6 \mathrm{H}^{+}+4 \mathrm{Cl}^{-}$

$2 \mathrm{NH}_{3} \rightarrow \mathrm{N}_{2}+6 \mathrm{H}^{+}+6 e^{-}$

$\mathrm{HOCl}$ : active chlorine; $\mathrm{NH}_{3}$ : ammonia; $\mathrm{NH}_{2} \mathrm{Cl}$ : chloramine; $\mathrm{NH}_{4}{ }^{+}$: ammonium; $\mathrm{NO}_{3}{ }^{-}$: nitrate.

Figure 6 shows that an increased current did increase the formation of $\mathrm{NO}_{3}{ }^{-}$on $\mathrm{Pt}$ anode at both, 6 and $20^{\circ} \mathrm{C}$. In contrary, $\mathrm{NO}_{3}{ }^{-}$formation decreased with increasing current on BDD anodes at both temperatures (additional data are given in SI: 7). This behaviour may be explained by the fact, that with an increasing current, the direct oxidation of $\mathrm{NH}_{3}$ to $\mathrm{N}_{2}$ governs $\mathrm{NH}_{3}$ oxidation on BDD anodes, while indirect oxidation via active chlorine becomes inferior. No direct $\mathrm{NH}_{3}$ oxidation takes places on $\mathrm{Pt}$ anodes but indirect oxidation of $\mathrm{NH}_{4}{ }^{+}$via $\mathrm{HOCl}$ to $\mathrm{NO}_{3}{ }^{-}$is promoted by increasing the applied current [36]. This leads consequently to higher formation of $\mathrm{NO}_{3}{ }^{-}$with an increased applied current. Cabeza et al. [37] observed an increase of $\mathrm{NH}_{4}{ }^{+}$removal from LL with an increasing applied current. This is because $\mathrm{NH}_{4}{ }^{+}$ oxidation is attributed to mainly occur via indirect oxidation by active chlorine generated via chloride oxidation in the electrolytic cell [38].

\subsection{Formation of disinfection by-products}

Formation of THMs was observed during all experiments (Fig. 7a-c), and statistical analysis of the total measured THM concentration for each experiment indicates that the applied current and the anode material, as well as their interaction effect, are significantly influencing their production. At $10 \mathrm{~mA} \mathrm{~cm}^{-2}$, the anode material has only a minor influence $\mathrm{CHCl}_{3}$ formation shows to be slightly higher at $\mathrm{BDD}$ anodes while formation of $\mathrm{CHCl}_{2} \mathrm{Br}, \mathrm{CHClBr}_{3}$ and $\mathrm{CHBr}_{3}$ seems to be favored at $\mathrm{Pt}$ anode. Increasing the current to 43 or $86 \mathrm{~mA} \mathrm{~cm}^{-2}$ increased the THMs formation proportionally. THM production is favored at $\mathrm{Pt}$ anode and differs by a factor a $1.8\left(6{ }^{\circ} \mathrm{C}\right.$ and $\left.43 \mathrm{~mA} \mathrm{~cm}^{-2}\right)$ to $8.3\left(6{ }^{\circ} \mathrm{C}\right.$ and $86 \mathrm{~mA} \mathrm{~cm}^{-2}$ ), whereby it is always less at BDD anodes for the same experimental settings. Jasper et al. [19] also observed a much lower THMs production on the non-active BDD anode compared to an active $\mathrm{TiO}_{2} / \mathrm{IrO}_{2}$ during EO of latrine wastewater. They attributed this observation to the fact that organic THMs precursors are much more rapidly mineralized to $\mathrm{CO}_{2}$ on BDD than on $\mathrm{Pt}$ anodes and 

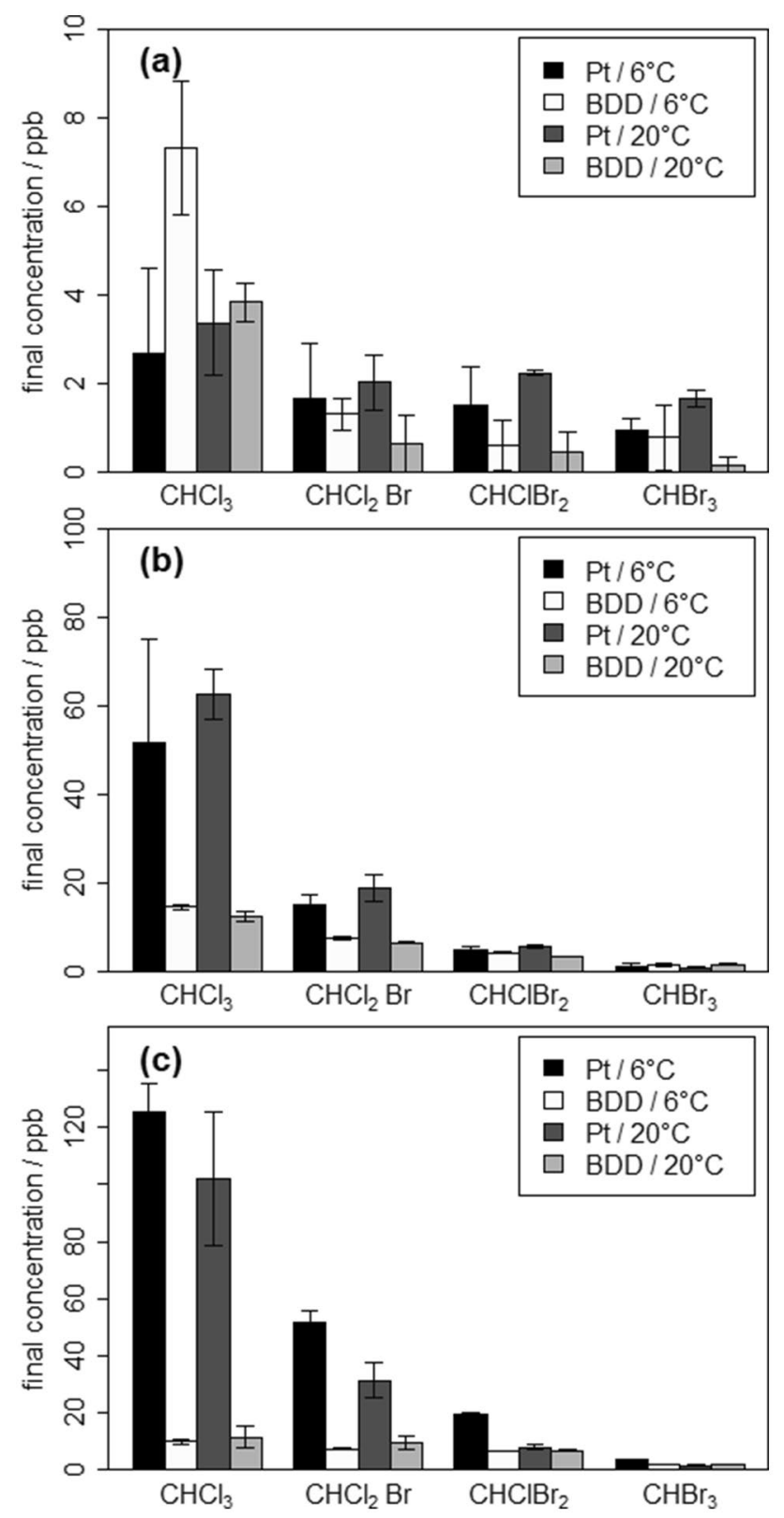

Fig. 7 Formation of THMs at three different applied currents

therefore less THMs are observed on BDD anodes. This is also in line with state-of-the-art literature that non-active anodes generally lead to faster mineralization of organic compounds than active anodes [7]. $\mathrm{CHCl}_{3}$ and $\mathrm{CHCl}_{2} \mathrm{Br}$ are formed in a greater amount than $\mathrm{CHBr}_{3}$ and $\mathrm{CHClBr}_{2}$, which is explained by the different initial $\mathrm{Cl}^{-}$and $\mathrm{Br}^{-}$concentrations of the LL, 157.0 and $2.1 \mathrm{mg} \mathrm{L}^{-1}$ respectively. Temperature had no statistical influence on the THMs formation. For $43 \mathrm{~mA} \mathrm{~cm}{ }^{-2}, 2{ }^{\circ} \mathrm{C}$ leads to a factor 1.8 higher THMs concentrations than $6{ }^{\circ} \mathrm{C}$, but for $86 \mathrm{~mA} \mathrm{~cm}^{-2}$ the opposite is observed (factor 1.9). Thus, it can be concluded that low temperature is of little importance for THM formation,

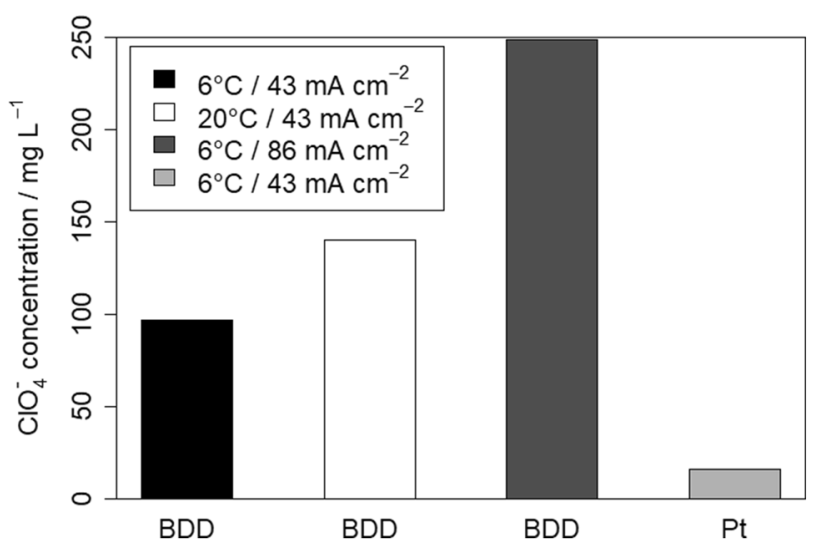

Fig. 8 Perchlorate Production at different temperatures, applied current and anode material (current is given per $\mathrm{cm}^{2}$ of active electrode area)

while the anode material must be carefully considered, and an appropriate applied current must be chosen in order to minimize their formation.

Based on the formation of THMs, BDD is the better choice. However, other studies showed that an extensive amount of perchlorate can be formed on BDD anodes during EO of chloride containing waters [39]. In the present study final concentrations of perchlorate $\left(\mathrm{ClO}_{4}^{-}\right)$were measured to proof its presence or absence during EO. Figure 8 shows the measured final $\mathrm{ClO}_{4}{ }^{-}$concentrations after an experimental time of $240 \mathrm{~min}$. On BDD anode, $96 \mathrm{mg} \mathrm{L}^{-1}$ of $\mathrm{ClO}_{4}^{-}$were produced, which corresponds to an $83 \%$ higher concentration than on the Pt electrode, where $16.1 \mathrm{mg} \mathrm{L}^{-1}$ have been found with otherwise similar experimental conditions. Furthermore, $\mathrm{ClO}_{4}^{-}$increased when either the temperature (140.2 $\left.\mathrm{mg} \mathrm{L}^{-1}\right)$ or the applied current $\left(248.8 \mathrm{mg} \mathrm{L}^{-1}\right)$ were increased. Compared to $6{ }^{\circ} \mathrm{C}$ and $\mathrm{BDD}$ anode, increasing the current caused the biggest difference in $\mathrm{ClO}_{4}{ }^{-}$production of $158 \%$. At an applied current of $10 \mathrm{~mA} \mathrm{~cm}^{-2}$ no $\mathrm{ClO}_{4}{ }^{-}$was detected for any temperature or anode material and is therefore not shown in Fig. 8. The observed formation of $\mathrm{ClO}_{4}{ }^{-}$in line with literature [19], where perchlorate was only discovered at the none-active BDD anode and THMs only at the active $\mathrm{TiO}_{2} / \mathrm{IrO}_{2}$ anode during $\mathrm{EO}$ of latrine wastewater. The fact that this study observed a small amount of perchlorate on Pt anode may be explained by the difference in the used active anode material and slightly different experimental conditions such as a higher applied current.

While THMs are volatile compounds that may disappear other time from the water phase, $\mathrm{ClO}_{4}{ }^{-}$may be of higher concern since it remains in the aqueous solution. In addition, THMs are formed in the ppb range on $\mathrm{Pt}$ anodes while $\mathrm{ClO}_{4}{ }^{-}$was formed in the ppm range on BDD anodes. Toxicity tests ( $96 \mathrm{~h}$, flow through) for fish (rainbow trout) show 
that the concentration which is lethal for $50 \%$ of the population $\left(\mathrm{LC}_{50}\right)$ corresponds to $36 \mathrm{mg} \mathrm{L}^{-1}$ for chloroform [40] and $2 \mathrm{mg} \mathrm{L}^{-1}$ for perchlorate [41]. Maximum perchlorate concentration reached on BDD anode was $237 \mathrm{mg} \mathrm{L}^{-1}$ and $16 \mathrm{mg} \mathrm{L}^{-1}$ on Pt anode. The maximum chloroform concentration reached on BDD anode was $15 \mu \mathrm{g} \mathrm{L}^{-1}$ and $136 \mu \mathrm{g}$ $\mathrm{L}^{-1}$ on $\mathrm{Pt}$ anode. This means that the perchlorate $\mathrm{LC}_{50}$ for fish was exceeded on both anode materials but to a much higher extent on the BDD anode. The $\mathrm{LC}_{50}$ for chloroform was not exceeded at neither anode material. In that regard, final perchlorate concentrations in this study cause higher toxicity than chloroform. This leads to the conclusion that Pt anode would be the favourable material with respect to DBP formation.

\subsection{Energy consumption}

The amount of energy, which was necessary for $99 \%$ removal of BPA and $1 \mathrm{~kg}$ of COD respectively, was estimated for the different experimental conditions (Fig. 9). The energy consumption was found to be on average $6 \%$ less on BDD anodes than on $\mathrm{Pt}$ when the same temperature and current
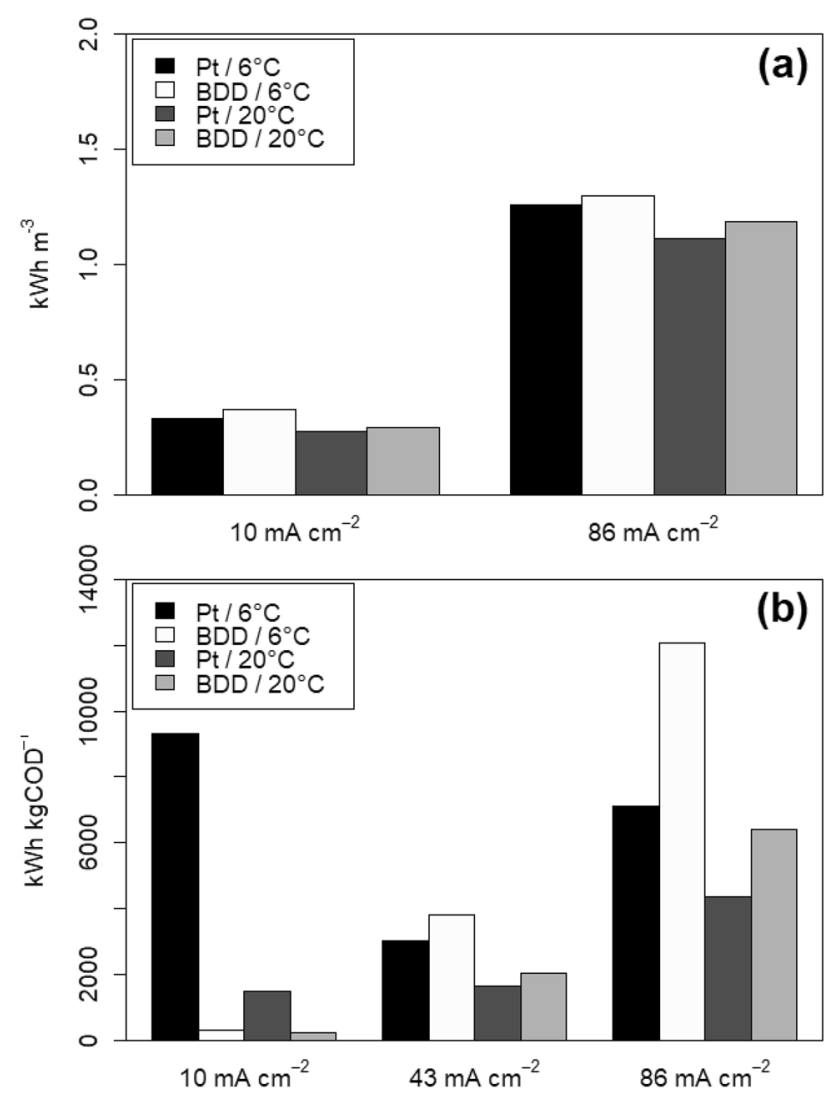

Fig. 9 a Energy consumption $\left(\mathrm{kWh} \mathrm{m}^{-3}\right)$ for $99 \%$ BPA removal; b estimated energy consumption for $1 \mathrm{~kg}$ COD removal were applied, since degradation of BPA was generally faster on BDD electrodes (Fig. 9a).

However, the applied current does affect the energy consumption to a greater extent. The average difference of energy consumption between 6 and $20^{\circ} \mathrm{C}$ corresponds to $12 \%\left(0.1 \mathrm{kWh} \mathrm{m}^{-3}\right)$. A bigger difference of the average energy consumption corresponding to $74 \%(0.9 \mathrm{kWh}$ $\mathrm{m}^{-3}$ ) was observed between 43 and $86 \mathrm{~mA} \mathrm{~cm}^{-2}$. It should be noted that no results are shown for a current density of $10 \mathrm{~mA} \mathrm{~cm}^{-2}$ in Fig. 9a, since BPA removal was not sufficient under these conditions. In other words, increasing the current from 43 to $86 \mathrm{~mA} \mathrm{~cm}{ }^{-2}$ means increasing the average energy consumption by $74 \%$ but reducing the treatment time by $48 \%$. Additionally, a LL temperature of 6 instead of $20^{\circ} \mathrm{C}$ increases the energy consumption on average by $12 \%$ and the treatment times by $25 \%$. Even though a high current would reduce the treatment time and higher energy consumption could be justified by low energy prices in Norway, it has to be kept in mind that a higher applied current also leads to the formation of more unwanted DBPs and thus the lower current seems to be the favorable choice. On the other hand, due to low energy prices in Norway $\left(0.11 € \mathrm{kWh}^{-1}\right)$ and the rather moderate difference in energy consumption between 6 and $20^{\circ} \mathrm{C}$, the EO of cold LL to remove organic pollutants like BPA is absolutely feasible. Almost $100 \%$ of the energy in Norway is produced by hydropower plants which also makes a higher energy consumption ecologically more reasonable. Furthermore, heat development in the electrolytical cell as well as the installed on-site pre-treatment would likely increase the LL temperature under more applied conditions, thus reducing the energy consumption during EO.

The COD removal within 240 min was linearly extrapolated to obtain the theoretical energy demand to remove $1 \mathrm{~kg}$ COD. Similar to BPA, an increasing energy consumption with increasing applied current of $7 \%$ and $65 \%$ for an increase from 10 to $43 \mathrm{~mA} \mathrm{~cm}^{-2}$ and from 43 to $86 \mathrm{~mA} \mathrm{~cm}^{-2}$ respectively was observed. As an exception to this observation, the removal of COD on Pt anode and $6{ }^{\circ} \mathrm{C}$, as can be seen in Fig. 9b, has a higher energy demand at $10 \mathrm{~mA} \mathrm{~cm}^{-2}$ than at 43 or $86 \mathrm{~mA} \mathrm{~cm}^{-2}$. Only $0.3 \%$ of the initial COD concentration (99.6 $\mathrm{mgO}_{2} \mathrm{~L}^{-1}$ ) were removed during $240 \mathrm{~min}$ for the given experimental conditions, resulting in an extraordinary long treatment time and subsequently in a higher energy consumption. Correspondingly, treatment times were shorter at the higher applied current, i.e. $92 \%$ and $25 \%$ for an increase from 10 to $43 \mathrm{~mA} \mathrm{~cm}^{-2}$ and from 43 to $86 \mathrm{~mA} \mathrm{~cm}^{-2}$ respectively. It can further be seen (Fig. 9b) that the energy consumption for COD removal is higher at 6 than at $20{ }^{\circ} \mathrm{C}$ for the otherwise same conditions, on average $55 \%$. The rationale for and against a higher current or temperature is the same as for BPA, stated above. 


\section{Conclusions}

The $99 \%$ removal of the organic pollutant Bisphenol A was achieved within the experimental time of $240 \mathrm{~min}$ on both tested anode materials ( $\mathrm{Pt}$ and $\mathrm{BDD})$ and at both tested temperatures $\left(6\right.$ and $\left.20^{\circ} \mathrm{C}\right)$. However, a current of at least $43 \mathrm{~mA} \mathrm{~cm}^{-2}$ must be applied. Corresponding treatment times differed on average by $25 \%$ ( $24 \mathrm{~min}$ ) and the equivalent energy consumption by $12 \%\left(0.1 \mathrm{kWh} \mathrm{m}^{-3}\right)$ between $6{ }^{\circ} \mathrm{C}$ and $20^{\circ} \mathrm{C}$. The best current efficiency was achieved at $86 \mathrm{~mA} \mathrm{~cm}^{-2}$ except for $6^{\circ} \mathrm{C}$ and BDD where $43 \mathrm{~mA} \mathrm{~cm}{ }^{-2}$ showed to be the most efficient current. The higher energy costs to maintain the most efficient current can be justified by low energy prices in Norway and thus making the process feasible for application.

Similar to Bisphenol A, a higher COD removal (6\%) was reached on average at $20{ }^{\circ} \mathrm{C}$ than at $6{ }^{\circ} \mathrm{C}$ for all experimental conditions and was higher on Pt than on BDD anodes except for $10 \mathrm{~mA} \mathrm{~cm}{ }^{-2}$. No complete COD removal was reached within the experimental time whereby maximum COD removal was $23 \%$.

The formation of trihalomethanes was observed during all experiments. On average, up to $76 \%\left(60 \mu \mathrm{g} \mathrm{L}^{-1}\right)$ more trihalomethanes were formed on Pt than on BDD anode and their formation increased with an increasing applied current. The temperature did not show a significant influence on the formation of the trihalomethanes. Contrary to the trihalomethanes, perchlorate formation mostly took place on BDD anodes with a maximum concentration of $260 \mathrm{mg} \mathrm{L}^{-1}$ while it was almost negligible on Pt anodes with a maximum observed concentration of $16 \mathrm{mg} \mathrm{L}^{-1}$. The formation of perchlorate was generally a factor 1000 higher than the formation of trihalomethanes, attaching more importance to the $\mathrm{Pt}$ anode that minimizes perchlorate production.

The findings of this study show that the electrochemical removal of organic pollutants (Bisphenol A) is possible from the leachate at cold temperatures without more extensive pretreatment like TOC, COD or $\mathrm{NH}_{4}{ }^{+}$removal. Nonetheless, further studies are suggested with a large-scale pilot plant to investigate the heat development within the electrolytical cells since this could be a beneficial aspect with regard to the removal kinetics in cold climates.

Author contributions Conceptualization: NA, CH, TM; Methodology: NA, CW, CH, TM; Formal analysis and Investigation: NA, CW; Visualization: NA, CW; Writing — original draft: NA; Writing—review and editing: NA, JM, TM; Funding acquisition: TM; Resources: TM; Supervision: JM, CH, TM.

Funding Open Access funding provided by NTNU Norwegian University of Science and Technology (incl St. Olavs Hospital - Trondheim University Hospital). This study was financially supported by the Norwegian University of Science and Technology and the Søndre Helgelands Miljøverk IKS, Norway.

\section{Compliance with ethical standards}

Conflict of interest The authors declare no conflict and no competing interests.

Open Access This article is licensed under a Creative Commons Attribution 4.0 International License, which permits use, sharing, adaptation, distribution and reproduction in any medium or format, as long as you give appropriate credit to the original author(s) and the source, provide a link to the Creative Commons licence, and indicate if changes were made. The images or other third party material in this article are included in the article's Creative Commons licence, unless indicated otherwise in a credit line to the material. If material is not included in the article's Creative Commons licence and your intended use is not permitted by statutory regulation or exceeds the permitted use, you will need to obtain permission directly from the copyright holder. To view a copy of this licence, visit http://creativecommons.org/licenses/by/4.0/.

\section{References}

1. Sirés I, Brillas E, Oturan MA et al (2014) Electrochemical advanced oxidation processes: today and tomorrow. A review. Environ Sci Pollut Res 21:8336-8367. https://doi.org/10.1007/ s11356-014-2783-1

2. Panizza M, Delucchi M, Sirés I (2010) Electrochemical process for the treatment of landfill leachate. J Appl Electrochem 40:1721-1727. https://doi.org/10.1007/s10800-010-0109-7

3. de Oliveira MS, da Silva LF, Barbosa AD et al (2019) Landfill leachate treatment by combining coagulation and advanced electrochemical oxidation techniques. ChemElectroChem 6:1427-1433. https://doi.org/10.1002/celc.201801677

4. Li J, Yang ZH, Xu HY et al (2016) Electrochemical treatment of mature landfill leachate using $\mathrm{Ti} / \mathrm{RuO}_{2}-\mathrm{IrO}_{2}$ and $\mathrm{Al}$ electrode: optimization and mechanism. RSC Adv 6:47509-47519. https:// doi.org/10.1039/c6ra05080h

5. Comninellis C (1994) Electrocatalysis in the electrochemical conversion/combustion of organic pollutants for waste water treatment. Electrochim Acta 39:1857-1862

6. Wang JL, Xu LJ (2012) Advanced oxidation processes for wastewater treatment: formation of hydroxyl radical and application. Crit Rev Environ Sci Technol 42:251-325. https://doi. org/10.1080/10643389.2010.507698

7. Comninellis C, Chen G (2010) Electrochemistry for the environment. Springer, New York

8. Martinez-Huitle CA, Ferro S (2006) Electrochemical oxidation of organic pollutants for the wastewater treatment: direct and indirect processes. Chem Soc Rev 35:1324-1340. https://doi.org/10.1039/ B517632H

9. Martínez-Huitle CA, Panizza M (2018) Electrochemical oxidation of organic pollutants for wastewater treatment. Curr Opin Electrochem 11:62-71. https://doi.org/10.1016/J.COELEC.2018.07.010

10. Wang J, Wang S (2016) Removal of pharmaceuticals and personal care products (PPCPs) from wastewater: a review. J Environ Manage 182:620-640. https://doi.org/10.1016/j.jenvman.2016.07.049

11. Xiao S, Peng J, Song Y et al (2013) Degradation of biologically treated landfill leachate by using electrochemical process combined with UV irradiation. Sep Purif Technol 117:24-29. https:// doi.org/10.1016/j.seppur.2013.04.024

12. Deblonde T, Cossu-Leguille C, Hartemann P (2011) Emerging pollutants in wastewater: a review of the literature. Int J Hydrogen Environ Health 214:442-448. https://doi.org/10.1016/j.ijheh .2011 .08 .002 
13. Jo EY, Lee TK, Kim Y, Park CG (2016) Effect of anions on the removal of bisphenol A in wastewater by electro-oxidation process. Desalin Water Treat 57:29500-29508. https://doi. org/10.1080/19443994.2016.1197156

14. Oturan N, Van Hullebusch ED, Zhang H et al (2015) Occurrence and removal of organic micropollutants in landfill leachates treated by electrochemical advanced oxidation processes. Environ Sci Technol 49:12187-12196. https://doi.org/10.1021/acs. est.5b02809

15. Lettinga G, Rebac S, Zeeman G (2001) Challenge of psychrophilic anaerobic wastewater treatment. Trends Biotechnol 19:363-370. https://doi.org/10.1016/S0167-7799(01)01701-2

16. Smith AL, Skerlos SJ, Raskin L (2013) Psychrophilic anaerobic membrane bioreactor treatment of domestic wastewater. Water Res 47:1655-1665. https://doi.org/10.1016/j.watres.2012.12.028

17. Kettunen RH, Hoilijoki TH, Rintala JA (1996) Anaerobic and sequential anaerobic-aerobic treatments of municipal landfill leachate at low temperatures. Bioresour Technol 58:31-40. https:// doi.org/10.1016/S0960-8524(96)00102-2

18. Ambauen N, Muff J, Tscheikner-Gratl F et al (2020) Application of electrochemical oxidation in cold climate regions-effect of temperature, $\mathrm{pH}$ and anode material on the degradation of Bisphenol A and the formation of disinfection by-products. J Environ Chem Eng 8:104183. https://doi.org/10.1016/j.jece.2020.104183

19. Jasper JT, Yang Y, Hoffmann MR (2017) Toxic byproduct formation during electrochemical treatment of latrine wastewater. Environ Sci Technol 51:7111-7119. https://doi.org/10.1021/acs. est.7b01002

20. Díaz V, Ibáñez R, Gómez P et al (2011) Kinetics of electrooxidation of ammonia-N, nitrites and COD from a recirculating aquaculture saline water system using BDD anodes. Water Res 45:125-134. https://doi.org/10.1016/j.watres.2010.08.020

21. Standard Norge NS-EN 1484 (1997) Water analysis-guidelines for the determination of total organic carbon (TOC) and dissolved organic carbon (DOC)

22. Panizza M, Cerisola G (2004) Influence of anode material on the electrochemical oxidation of 2-naphthol part 2. Bulk Electrolysis Exp 49:3221-3226. https://doi.org/10.1016/j.elect acta.2004.02.036

23. Cañizares P, Domínguez JA, Rodrigo MA et al (1999) Effect of the current intensity in the electrochemical oxidation of aqueous phenol wastes at an activated carbon and steel anode. Ind Eng Chem Res 38(10):3779-3785. https://doi.org/10.1021/ie9901574

24. Muff J, Søgaard EG (2010) Electrochemical degradation of PAH compounds in process water: a kinetic study on model solutions and a proof of concept study on runoff water from harbour sediment purification. Water Sci Technol 61:2043-2051. https://doi. org/10.2166/wst.2010.129

25. Ambauen $\mathrm{N}$ et al (2019) Insights into the kinetics of intermediate formation during electrochemical oxidation of the organic model pollutant salicylic acid in chloride electrolyte. Water 11:1322. https://doi.org/10.3390/w11071322

26. Fang J, Fu Y, Shang C (2014) The roles of reactive species in micropollutant degradation in the UV/free chlorine system. Environ Sci Technol 48:1859-1868. https://doi.org/10.1021/es403 6094

27. Liao CH, Kang SF, Wu FA (2001) Hydroxyl radical scavenging role of chloride and bicarbonate ions in the $\mathrm{H}_{2} \mathrm{O}_{2} / \mathrm{UV}$ process.
Chemosphere 44:1193-1200. https://doi.org/10.1016/S0045 $-6535(00) 00278-2$

28. El Hachemi ME, Naffrechoux E, Suptil J, Hausler R (2013) Bicarbonate effect in the ozone-UV process in the presence of nitrate. Ozone Sci Eng 35:302-307. https://doi.org/10.1080/01919 512.2013.794650

29. Norwegian Environment Agency (2016) Grenseverdier for klassifisering av vann, sediment og biota. 24

30. Zhou M, Liu L, Jiao Y et al (2011) Treatment of high-salinity reverse osmosis concentrate by electrochemical oxidation on BDD and DSA electrodes. Desalination 277:201-206. https:// doi.org/10.1016/J.DESAL.2011.04.030

31. de Moura DC, do Nascimento Brito C, Quiroz MA et al (2015) Clmediated electrochemical oxidation for treating an effluent using platinum and diamond anodes. J Water Process Eng 8:e31-e36. https://doi.org/10.1016/j.jwpe.2014.11.005

32. Kapałka A, Joss L, Anglada Á et al (2010) Direct and mediated electrochemical oxidation of ammonia on boron-doped diamond electrode. Electrochem commun 12:1714-1717. https://doi. org/10.1016/j.elecom.2010.10.004

33. Qiang Z, Adams CD (2004) Determination of monochloramine formation rate constants with stopped-flow spectrophotometry. Environ Sci Technol 38:1435-1444. https://doi.org/10.1021/es034 7484

34. (1984) International Standard ISO 7510/1 Water quality-Determination of ammonium-Part 1: manual spectrometric method

35. Li L, Liu Y (2009) Ammonia removal in electrochemical oxidation: mechanism and pseudo-kinetics. J Hazard Mater 161:1010 1016. https://doi.org/10.1016/j.jhazmat.2008.04.047

36. Panizza M, Cerisola G (2006) Olive mill wastewater treatment by anodic oxidation with parallel plate electrodes. Water Res. https ://doi.org/10.1016/j.watres.2006.01.020

37. Cabeza A, Urtiaga A, Rivero MJ, Ortiz I (2007) Ammonium removal from landfill leachate by anodic oxidation. J Hazard Mater 144:715-719. https://doi.org/10.1016/j.jhazmat.2007.01.106

38. Chiang LC, Chang JE, Wen TC (1995) Indirect oxidation effect in electrochemical oxidation treatment of landfill leachate. Water Res 29:671-678. https://doi.org/10.1016/0043-1354(94)00146-X

39. Tian Y, Zhu X, Ye J et al (2017) Influencing factors and chlorinated byproducts in electrochemical oxidation of bisphenol A with boron-doped diamond anodes. Electrochim Acta 246:1121-1130. https://doi.org/10.1016/j.electacta.2017.06.163

40. United States. Environmental Protection Agency. Office of Water Planning and Standards. Criteria and Standards Division (1979) Ambient Water Quality Criteria. Criteria and Standards Division, Office of Water Planning and Standards, U.S. Environmental Protection Agency

41. Dean KE, Palachek RM, Noel JM et al (2004) Development of freshwater water-quality criteria for perchlorate. Environ Toxicol Chem 23:1441-1451. https://doi.org/10.1897/02-648

Publisher's Note Springer Nature remains neutral with regard to jurisdictional claims in published maps and institutional affiliations. 